\title{
RELASI KUASA PADA PERNIKAHAN POLIGAMI DALAM PERSPEKTIF KEKERASAN SIMBOLIK
}

\author{
Maulana Hazmi \\ Program Studi Sosiologi, Fakultas Ilmu Sosial, Universitas Negeri Jakarta \\ maulhzm1997@gmail.com \\ Diterima Redaksi: 24-03-2021 | Selesai Direvisi: 23-05-2021 | Diterbitkan Online 04-06-2021
}

\begin{abstract}
This research is based on a phenomenon that occurs in society regarding polygamous marriage. This study aims to describe what makes women willing to be polygamous and what kind of relationship exists between husband and wife in a polygamous family. This research uses a qualitative approach with a case study method. Data collection techniques used are through observation techniques, in-depth interviews, documentation and literature study on related documents. The results showed, in polygamous marriages, religion is used and believed to be the dominant discourse. Capital accumulation affects the position of husband and wife in the family, including economic, social, cultural and symbolic capital, this discourse battle is dominated by the husband, so that the husband can determine the values used. This form of domination carried out by the husband and not realizing the domination by the wife who works subtly is called by Bourdieu as a form of symbolic violence.
\end{abstract}

Keywords: Polygamy, Family, Domination, Symbolic Violence

\begin{abstract}
Abstrak
Penelitian ini dilandasi oleh fenomena yang terjadi di masyarakat mengenai pernikahan poligami. Penelitian ini bertujuan untuk mendeskripsikan tentang apa yang melatarbelakangi perempuan untuk bersedia dipoligami dan relasi seperti apa yang terjalin antara suami dan istri dalam keluarga poligami. Penelitian ini menggunakan pendekatan kualitatif dengan metode studi kasus. Teknik pengumpulan data yang digunakan adalah melalui teknik observasi, wawancara secara mendalam, dokumentasi dan studi pustaka pada dokumen terkait. Hasil penelitian menunjukkan, dalam pernikahan poligami, agama digunakan dan dipercayai sebagai wacana dominan. Akumulasi modal mempengaruhi posisi suami dan istri dalam keluarga, diantaranya adalah modal ekonomi, sosial, budaya, dan simbolik, pertarungan wacana ini didominasi oleh suami, sehingga suami dapat menentukan nilai-nilai yang digunakan. Bentuk dominasi yang dilakukan oleh suami dan tidak disadarinya dominasi oleh istri yang bekerja secara halus ini dinamakan oleh Bourdieu sebagai bentuk kekerasan simbolik.
\end{abstract}

Kata Kunci: Poligami, Keluarga, Dominasi, Kekerasan Simbolik 


\section{Pendahuluan}

Poligami adalah perkawinan dengan lebih dari satu pasangan pada saat yang sama. Jika seorang pria mengawini lebih dari satu orang perempuan, ini disebut dengan poligini. Dan poliandri jika seorang wanita memiliki lebih dari satu suami (Baswardono, 2007:44). Dalam penerapannya fenomena poligami masih seringkali menjadi pro dan kontra dalam kehidupan masyarakat di Indonesia. Mereka yang pro terhadap poligami membolehkan poligami asal dilakukan dengan menggunakan asas keadilan dan tidak merugikan kaum perempuan, namun mereka yang kontra terhadap poligami memandang bahwa poligami merupakan salah satu bentuk diskriminasi dan melemahkan hak-hak perempuan (Hikmah, 2012:6).

Pembenaran praktik poligami dengan menggunakan dalil-dalil agama dan berdasarkan syariat agama Islam yang dilegitimasi dengan menggunakan ayat-ayat suci menjadi kontroversial karena di dalam pemaknaan kontekstual dalil-dalil agama dan ayat suci sangatlah beragam, Menurut Baswardono, tidaklah bijak apabila suami hanya mengungkapkan pemaknaan yang dianggap benar olehnya sedangkan mungkin sang suami tidak menyampaikan ragam-ragam pemaknaan yang lainnya termasuk firman-firman Tuhan yang dapat mencegah dan meminimalisasi praktik poligini. Para suami tidak memberikan kebebasan kepada perempuan untuk melakukan dan memahami firman tuhan atas pemikirannya sendiri (Baswardono, 2007:27).

Poligami dapat dikatakan sebagai salah satu bentuk diskriminasi dan merugikan perempuan. Namun yang menjadi masalah selanjutnya adalah para perempuan yang dipoligami menerima dengan lapang dada dan ikhlas menjalani pernikahan ini, mereka menganggap bahwa dengan dipoligami mereka akan mendapatkan pahala yang besar, karena poligami ini merupakan ajaran agama dan sebagai bentuk pengabdian terhadap suami. Hal ini yang dinamakan dengan Bourdieu sebagai kekerasan simbolik atau kekerasan yang tak kasat mata. Kekerasan semacam ini oleh korbannya (kaum perempuan) bahkan tidak dilihat dan dirasakan sebagai kekerasan, tetapi dianggap sebagai sesuatu yang alamiah dan wajar. Hal ini bisa terjadi karena penguasaan wacana yang dilakukan oleh laki-laki (patriarki) menjadikan dominasi lakilaki seakan-akan menjadi tampak wajar dan bisa diterima (Haryatmoko, 2016:57). Permasalahan ini menarik untuk dikaji lebih dalam untuk melihat bagaimana sebenarnya relasi laki-laki dan perempuan (istri) dalam praktik pernikahan poligami, apakah terjadi proses diskriminasi ataukah sudah setara dengan laki-laki (suami). 
Berdasarkan latar belakang masalah yang telah dipaparkan di atas, diketahui bahwa memang dalam penerapannya pernikahan poligami telah disetujui oleh istri pertama, namun yang menjadi masalah adalah di dalam pengambilan keputusan istri tentu tidak lepas dari pengaruh eksternal dari dirinya, pengaruh dari suami tentu saja menjadi salah satu pertimbangan istri. Pengaruh ini diberikan dengan cara pemberian dan penanaman nilai-nilai agama yang dianggap benar oleh suami, penanaman nilai-nilai agama yang mendukung pernikahan poligami ditanamkan kepada sang istri. Maka dari itu dibutuhkan kajian lebih lanjut mengenai kedudukan dan relasi perempuan dalam pernikahan poligami serta bagaimana relasi yang terjadi antara suami dan istri dalam keluarga poligami. Permasalahan penelitian yang diangkat oleh penulis adalah tentang apa yang melatarbelakangi perempuan bersedia dipoligami dan bagaimana relasi kuasa yang terjalin pada keluarga poligami.

Tujuan penelitian ini adalah untuk mendeskripsikan hal-hal yang melatarbelakangi perempuan hingga akhirnya bersedia dipoligami, selain itu untuk mendeskripsikan bagaimana relasi kuasa yang terjalin antara suami dan istri khususnya pada tiga keluarga poligami yang diteliti dengan menggunakan analisis Pierre Bourdieu mengenai konsep kekerasan simbolik. Hasil penelitian ini dapat dijadikan sebagai bahan pustaka untuk pengembangan ilmu Sosiologi Keluarga, khususnya dalam permasalahan mengenai praktik pernikahan poligami yang ditinjau dengan menggunakan kajian sosiologi keluarga dan sosiologi gender, selain itu penelitian ini dapat menjadi referensi bagi peneliti selanjutnya yang memiliki topik sama yaitu tentang mengenai praktik pernikahan poligami, serta Memberikan sumbangan pengetahuan bagi para pembaca mengenai permasalahan praktik pernikahan poligami serta tentang bagaimana relasi yang terjalin antar anggota keluarga dalam keluarga yang berpoligami.

\section{Metode Penelitian}

Penelitian ini menggunakan pendekatan kualitatif dengan metode studi kasus, alasan peneliti menggunakan pendekatan kualitatif adalah agar peneliti dapat menjelaskan suatu fenomena dengan sedalam-dalamnya dengan cara pengumpulan data yang sedalam-dalamnya pula (Nurdin dan Hartati, 2019:76). Selain itu dengan menggunakan metode studi kasus, peneliti dapat memahami dan menjelaskan tentang latar belakang suatu persoalan, atau interaksi individu di dalam suatu unit sosial atau mengenai suatu kelompok individu secara mendalam (Nurdin dan Hartati, 2019:80).

Dalam menentukan instrumen penelitian, peneliti memilih informan yang akan dijadikan sebagai sumber informasi adalah keluarga yang tergabung dalam organisasi khususnya 
organisasi keluarga dan organisasi agama. Alasan yang melatarbelakangi dipilihnya informan melalui organisasi keluarga dan organisasi agama adalah karena peneliti ingin melihat peranan organisasi-organisasi ini dalam fenomena pernikahan poligami. Validasi data yang digunakan dalam penelitian ini adalah melalui wawancara dengan organisasi keluarga yang kontra dengan pernikahan poligami, hal ini dilakukan guna memperkaya data dan sudut pandang dalam penelitian kali ini. Selain itu penulis juga menggunakan media internet guna melakukan riset pustaka sebagai tambahan data dan alat untuk validasi data.

\section{Hasil dan Pembahasan}

\section{Pandangan Poligami Dalam Berbagai Perspektif Keagamaan}

Organisasi Perempuan Muslimat NU menganggap bahwa monogami merupakan bentuk perkawinan yang paling ideal. Menurut organisasi ini poligami dapat dibolehkan sebagai "pintu darurat" asal dilakukan oleh orang tertentu dan dalam keadaan tertentu. Seorang suami sebelum berpoligami sebaiknya dilihat kesiapan dan kemampuan dari suami tersebut, seperti kemampuan untuk memberikan nafkah baik secara lahir maupun batin, mampu mengangkat derajat perempuan, menyiarkan dakwah islami, ketidakmampuan istri untuk melayani suami dan yang paling penting adalah mampu untuk berlaku adil (Zulkarnaen, 2011:30).

Organisasi Aisyiyah Muhammadiyah memandang bahwa prinsip monogami sebenarnya menjadi prinsip pernikahan dalam hukum Islam bila merujuk pada al-Qur'an dan hadis. Organisasi ini berpendapat bahwa poligami harus dihindari karena dikhawatirkan tidak dapat berlaku adil, sulitnya mengukur keadilan dengan begitu akan menimbulkan penderitaan dalam sebuah rumah tangga. Menurut organisasi ini keluarga yang sakinah harus dibangun dalam pondasi-pondasi yang kokoh. Al-Qur'an senantiasa mengajarkan dan memberikan contoh penegakan keadilan, serta melarang dan mencegah perbuatan yang menjurus pada ketidakadilan yang berpotensi menyakiti orang lain (Muthmainah, 2019:127).

Menurut Siti Musdah Mulia alasan-alasan yang dibuat untuk memperbolehkan pernikahan poligami hanya dilihat dari perspektif kepentingan suami, dan sama sekali tidak mempertimbangkan perspektif perempuan. Tidak pernah dipertimbangkan, misàlnya andaikata suami tidak mampu menjalankan kewajibannya sebagai suami, atau suami mendapat cacat atau penyakit, atau suami mandul apakah istri boleh menikah lagi? (Sulaiman, 2019:83).

Lebih jauh Siti Musdah Mulia melihat bahwa hakekat poligami adalah selingkuh yang dilegalkan, dan karenanya jauh lebih menyakitkan perasaan istri. Islam menuntun manusia agar menjauhi selingkuh, dan sekaligus menghindari poligami. Islam menuntun pengikutnya: laki- 
laki dan perempuan agar mampu menjaga organ-organ reproduksinya dengan benar sehingga tidak terjerumus pada segala bentuk pemuasan syahwat yang dapat mengantarkan pada kejahatan terhadap kemanusiaan (Sulaiman, 2019:88).

\section{Keluarga Poligami Sebagai Arena Kontestasi Makna}

Agama sebagai sistem simbol memuat skema tanda tertentu yang merepresentasikan realitas tertentu pula. Daya simbol berperan membuka ruang komunikasi dan interpretasi terhadap tanda-tanda yang disebarkannya (Dilliston, 2002:18). Dalam kasus poligami, ajaran keagamaan yang mendukung dilakukannya poligami digunakan sebagai sistem simbol yang digunakan untuk membentuk interpretasi istri untuk menerima dipoligami. Pemberian pemahaman ajaran keagamaan tersebut bertujuan untuk membentuk pemahaman bagi istri bahwa sebenarnya poligami itu diperbolehkan oleh agama dan terdapat dalam syariat agama Islam.

Dominasi simbolik memuat kuasa simbolik sebagai bentuk kuasa yang dapat membuat orang mengenali dan mempercayai, memperkuat dan mengubah pandangan mengenai dunia. Kuasa simbolik bekerja melalui pengendalian simbol dan mengonstruksi realitas melalui tata simbol tersebut. Kuasa simbolik bisa diandaikan sebagai kekuatan magis guna membuat individu, kelompok, atau masyarakat patuh melalui mobilitas tata simbol. Ketika mereka yang didominasi menerima begitu saja atau tidak menyadari pemaksaan yang ditanamkan lewat simbol-simbol, maka saat itulah praktik dominasi simbolik bekerja (Bourdieu, 1991:164).

Dalam keluarga poligami, keluarga merupakan sebuah arena kontestasi antara suami dan istri dalam menentukan siapa yang mengendalikan sumber wacana dalam keluarga. Menurut Bourdieu dan Wacquant, Arena merupakan hubungan yang terstruktur dan secara tidak sadar mengatur posisi individu, kelompok, atau lembaga dalam tatanan masyarakat yang terbentuk secara spontan. Ranah merupakan arena kekuatan yang di dalamnya terdapat upaya perjuangan untuk memperebutkan sumber daya (modal) dengan hierarki kuasa (Bourdieu dan Waqcuant, 1992:97).

Seperti data lapangan yang ditemukan, dalam kasus pernikahan poligami, keluarga dijadikan sebagai arena kontestasi antara suami dan istri. Kontestasi ini dipengaruhi oleh modal dan habitus yang pada akhirnya menentukan posisi antara suami dan istri dalam keluarga poligami. Posisi-posisi ini tentu memiliki beberapa perbedaan, dimana salah satu aktor akan mendominasi atau menjadi superordinat dan aktor yang lainnya akan didominasi atau menjadi subordinat. Dalam kasus poligami, kontestasi dilakukan untuk memperebutkan sumber daya 
dan memperoleh akses tertentu. Hal ini yang pada akhirnya membuat aktor yang mendominasi dapat membentuk persepsi, mendapatkan legitimasi, serta dianggap sebagai struktur yang objektif.

Selanjutnya menurut Bourdieu, dalam suatu ranah, terdapat pertaruhan, kekuatankekuatan, dan orang yang memiliki modal besar dan orang yang tidak memiliki modal. Modal merupakan sebuah konsentrasi kekuatan, suatu kekuatan spesifik yang beroperasi dalam sebuah ranah. Ranah yang dimaksud disini bukan saja mengenai artian ranah sebagai ranah kekuatan, tetapi pada saat yang sama ia adalah ranah, di mana orang-orang berjuang untuk mengubah struktur. Dengan demikian ranah kekuatan dalam artian yang sama juga sebagai ranah perjuangan. Konsep ranah mengandaikan hadirnya berbagai macam potensi yang dimiliki oleh individu, maupun kelompok dalam posisinya masing-masing. Tidak hanya sebagai arena kekuatan, ranah juga merupakan arena perjuangan demi memperebutkan posisiposisi di dalamnya. Posisi-posisi tersebut ditentukan oleh alokasi modal atas para pelaku yang mendiami suatu ranah (Bourdieu, 1993:30).

Dalam fenomena pernikahan poligami seperti temuan dalam riset ini, kontestasi ini pada akhirnya dimenangkan oleh suami, hal ini bisa terjadi karena alokasi modal dan habitus yang dimiliki oleh para suami, khususnya di ketiga keluarga yang menjadi kasus studi ini lebih besar daripada yang dimiliki oleh istri. Kemenangan yang diperoleh oleh suami ini yang pada akhirnya membuat suami berhak untuk menciptakan semesta makna yang dipercayai kebenarannya dan digunakan dalam keluarga. Pernyataan tersebut dapat dijelaskan melalui skema No. 1 di bawah ini: 


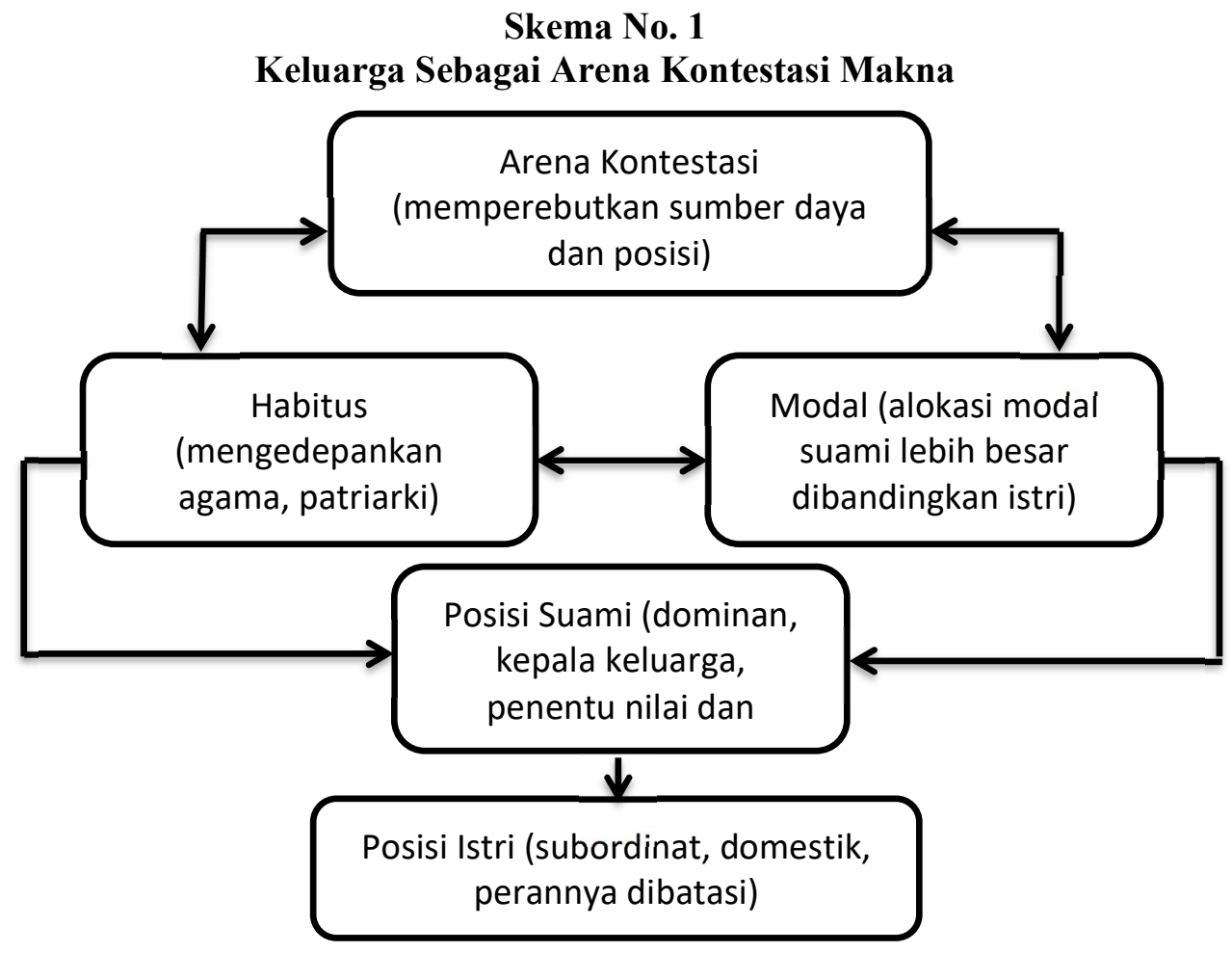

Hasil Interpretasi Penulis (2021)

Argumentasi dari skema IV.1 di atas menjelaskan bahwa arena kontestasi, habitus, dan modal saling berkesinambungan dan saling mempengaruhi satu dengan yang lainnya. Ketiga hal ini yang pada akhirnya menentukan posisi antara suami dan istri dalam keluarga poligami, berdasarkan penelitian yang sudah dilakukan, didapati bahwa suami memiliki alokasi modal dan habitus yang lebih besar dan menjadi aktor yang superordinat dalam keluarga poligami sedangkan perempuan berposisi sebagai subordinat. Argumen dari hal tersebut akan dipaparkan pada bagian-bagian di bawah ini.

\section{Peran Habitus Dalam Keluarga Poligami}

Pemikiran Bourdieu tentang habitus menjelaskan secara mendasar prinsip-prinsip kehidupan sosial sehari-hari beserta keteraturan yang mengiringinya. Habitus dapat dirumuskan sebagai sistem kecenderungan-kecenderungan (skema-skema persepsi, pola pikir, dan tindakan) yang diperoleh dari struktur sosial dan pengalaman aktor dan bertahan lama. Habitus juga merupakan gaya hidup, nilai-nilai, watak, dan harapan kelompok sosial tertentu. Bourdieu menyatakan bahwa habitus adalah struktur mental yang digunakan untuk memahami dunia sosial, struktur mental ini merupakan produk utama hasil internalisasi struktur dunia sosial (Bourdieu, 1991:170). 
Habitus merupakan bentuk pemahaman yang menjadi perilaku yang tidak selalu disadari, sehingga terlihat bahwa ini merupakan kemampuan alamiah. Habitus ini dikonstruksi melalui proses pengasuhan, aktivitas bermain, dan juga pendidikan masyarakat dalam artian yang cukup luas. Uniknya proses yang membentuk pengalaman ini terjadi secara halus, sehingga seseorang tak menyadarinya sehingga seolah-olah sebagai sesuatu yang alamiah dan bersifat kodrati (Takwin, 2006:35).

Seperti data lapangan yang ditemukan, keluarga poligami yang dilandasi oleh pemahaman agama yang dianggap sebagai sebuah struktur objektif. Suami yang berposisi sebagai superordinat memproduksi habitus-habitus yang dapat meredam resistensi dari perempuan, sehingga perempuan tidak mampu untuk memproduksi habitusnya sendiri. Dalam kasus yang ada di lapangan para suami pada tiga keluarga dalam studi ini seringkali memberikan dan melekatkan pemahaman bahwa sudah menjadi kodratnya perempuan untuk patuh dan taat pada suami, memberikan pemahaman bahwa poligami itu dibolehkan oleh syariat agama Islam, memposisikan suami sebagai penentu nilai dan norma. Pembatinan struktur objektif seperti ini yang pada akhirnya membentuk skema berpikir istri dan dianggap sebagai hal yang wajar. Seperti yang dikemukakan oleh Rrm dalam wawancaranya, yaitu:

"Latar belakang saya berpoligami ya karena saya suka lagi aja dengan perempuan lain, saya memiliki ketertarikan dengan lawan jenis selain istri saya, lagian juga diperbolehkan kok sama agama, poligami kan juga termasuk dalam syariat agama Islam, hukum tentang poligami itu ada dalam Al-Quran surah An nisa, jadi memang diperbolehkan kok oleh agama, lagian saya juga bisa ngasih rumah, ngasih nafkah, istri saya juga mendukung saya untuk berpoligami kok, maka dari itu saya merasa siap untuk berpoligami.",4

Penjabaran diatas diperkuat dengan adanya anggapan bahwa perempuan muslim diwajibkan untuk percaya dan taat pada syariat-syariat agama Islam, termasuk syariat tentang poligami, menjadi istri yang secara penuh menerima syariat agama dan rela untuk diatur kehidupannya oleh Tuhan. Seperti yang dikemukakan oleh Istri kedua Hfd dalam wawancaranya, yakni:

"Sebenarnya tidak ada perempuan yang ingin dipoligami mas, tapi saya kan bukan hanya perempuan biasa, tetapi saya seorang muslimah, tugas seorang muslimah itu harus percaya dan taat pada perintah dan syariat agama, perempuan yang secara total menerima syariat agama dan pasrah diatur oleh Allah SWT, makanya saya menerima poligami sebagai bentuk ketakwaan kepada Allah SWT dan agama."

\footnotetext{
${ }^{4}$ Hasil wawancara dengan Rrm (35 Tahun), penggiat poligami yang tergabung dalam Yayasan Keluarga Samara, di Bandung pada Jumat, 27 November 2020.

${ }^{5}$ Hasil wawancara dengan istri kedua Hfd (48 Tahun), di Banten pada Minggu, 08 November 2020.
} 
Hal ini diperkuat dengan pernyataan bahwa memang sudah menjadi peranan suami untuk menuntun istrinya dengan memberikan pemahaman-pemahaman tentang agama, karena terdapat anggapan bahwa suami mampu memberikan penjelasan tentang ajaran keagamaan dengan lebih rinci, karena suami dianggap lebih paham ilmunya daripada istri. Seperti yang dikemukakan oleh Rumiyati dalam wawancaranya, yang menyatakan bahwa:

"kan memang sudah menjadi tugas seorang suami untuk menuntun istrinya menuju ke surganya Allah SWT, jadi memang kalo suami saya itu memberikan pemahaman-pemahaman tentang ilmu agama termasuk poligami itu melalui diskusi-diskusi seperti itu, tapi kita juga sebagai istri tidak bisa memaksakan pemahaman kita pada suami, karena kan memang sudah kodratnya suami untuk lebih menggunakan akalnya, kalo perempuan kan kebanyakan menggunakan perasaan, suami juga lebih rinci kalo menjelaskan ke saya kalo saya ada pertanyaan tentang agama."6

Berdasarkan data di lapangan didapati bahwa pada tiga keluarga poligami yang diteliti. Pada keluarga Hfd, suami memberikan pemahaman tentang poligami kepada istri secara rutin, diantaranya pada saat makan bersama, sebelum tidur dan pada pertemuan keluarga. Hal ini dilakukan agar kerangka berpikir istri tentang poligami terbentuk sesuai dengan keyakinan suami. Selanjutnya pada keluarga Egd suami dan istri sama-sama belajar dan mendalami perihal poligami melalui komunitas-komunitas keagamaan, dalam komunitas tersebut istri diberikan pemahaman-pemahaman tentang poligami, dalam komunitas tersebut sesama istri poligami saling menguatkan satu sama lain. Selain itu pada keluarga Rrm cara untuk meluluhkan hati seorang istri bisa dilakukan dengan cara pemberian pemahaman dan dengan tindakan, seperti pemberian porsi kasih sayang yang lebih lagi kepada istri. Apabila istri tidak bersedia dipoligami, suami harus menanyakan alasan istri tidak mau dipoligami, dicari akar masalahnya, pencarian ini bertujuan untuk menghilangkan prasangka buruk istri tentang poligami. Seperti yang dikemukakan oleh Rrm dalam wawancaranya, yakni:

"Menurut keyakinan saya, cara untuk meyakinkan istri suapa mau dipoligami adalah dengan cara ngobrol, gak ada cara lain, karena kerangka berpikir suami dan istri tentang poligami itu harus sama dulu, kita juga harus menyamakan bidang pengalaman kita dengan istri, sehingga irisan tentang poligami antara suami dan istri semakin besar, dengan begitu kita bisa menghilangkan prasangka dari istri, seperti takut gak disayang, takut diabaikan, dan takut ditinggal. Tapi keluarga kita juga harus sejahtera dulu baru bisa seperti itu."7

\footnotetext{
${ }^{6}$ Hasil wawancara dengan Rmy (30 Tahun), istri kedua Egd, di Bandung pada Jumat, 27 November 2020.

${ }^{7}$ Hasil wawancara dengan Rrm (35 Tahun), penggiat poligami yang tergabung dalam Yayasan Keluarga Samara, di Bandung pada Jumat, 27 November 2020.
} 
Penerimaan poligami oleh istri pada tiga keluarga poligami ini terdapat berbagai macam hal yang melatarbelakangi, diantaranya pada keluarga Hfd terdapat argumen bahwa rumus keluarga yang harmonis adalah suami ditaati dan istri harus patuh dan taat pada suami. Pada keluarga Egd istri tidak boleh memiliki kendali atas keluarga. Selain itu pada keluarga Rrm penanaman pemahaman-pemahaman tentang poligami dan tugas seorang istri harus patuh dan taat pada suami terus ditanamkan pada istri, hal ini dilakukan berupaya untuk membentuk kerangka berpikir istri yang telah ditentukan oleh suami. Seperti yang diunkapkan oleh Hfd dalam wawancaranya, yaitu:

"Poligami itu kan urusannya laki-laki sebagai kepala rumah tangga, gak ada tuh saya ijin-ijinan sama istri, saya cuma ngasih tau bahwa saya ingin menikah lagi sudah. Jadi kan memang sudah jadi tugas suami untuk mendidik dan membimbing istrinya agar patuh dan taat pada suami, kalo saya sendiri berusaha untuk merekayasa dan membentuk keyakinan istri saya agar disiplin, kan memang sudah menjadi kodratnya perempuan untuk patuh sama suami, jadi kalo ada perempuan yang gak mau dipoligami, ya yang harus dipertanyakan itu laki-lakinya, gak mampu itu dia untuk mendidik istri." 8

Upaya pembentukan habitus yang akan menjadi resistensi bagi langgengnya struktur objektif diredam dengan cara membatasi peranan istri dalam keluarga, seperti pada kasus keluarga Hfd istri hanya mengurusi urusan domestik, minimnya keterlibatan istri dalam permasalahan yang ada dalam keluarga, mengurus anak, dan melayani suami. Selain itu cara lain untuk meredam resistensi dari istri, seperti pada kasus keluarga Egd dan Rrm yang memasukan istrinya ke dalam komunitas keagamaan yang berorientasi pada pernikahan poligami.

Pemahaman yang diterima oleh istri didapatkan dari komunitas keagamaan, dalam komunitas tersebut sesama istri saling bercerita tentang keluh kesahnya dalam keluarga poligami, diskusi, mencari solusi dari kasus per kasus yang terjadi dalam keluarga poligami. Selain itu suami tetap memberikan pemahaman-pemahamannya tentang nilai agama dan nilai tauhid kepada istri. Sehingga tertanam pola pikir yang sesuai dengan yang diarahkan oleh suami.Seperti yang dikemukakan oleh Egd dalam wawancaranya, yaitu:

"Pemahaman istri saya tentang poligami itu diperkuat lewat komunitas-komunitas sih, disana mereka bisa saling sharing, berbagi pengalaman, diskusi tentang kasus-kasus yang

\footnotetext{
${ }^{8}$ Hasil wawancara dengan Hfd (48 Tahun), Penggiat Poligami, sekaligus direktur Robbanian Family, di Banten pada, Minggu, 08 November 2020.
} 
terjadi, tetapi saya juga sebagai suami tetap belajar dan mengingatkan tentang tauhid kepada istri dan nilai agama, sehingga tertanam mindset dari istri saya."9

Dalam organisasi tersebut wanita diberikan pemahaman-pemahaman untuk mengarahkan pada dibolehkannya suami untuk berpoligami, komunitas tersebut juga menjadi wadah untuk istri-istri yang dipoligami untuk saling berbagi cerita tentang permasalahan yang terjadi dalam keluarga poligami, sehingga dapat dicarikan solusi terbaik demi menjaga langgengnya pernikahan poligami. Komunitas juga berperan sebagai sistem penguatan istriistri yang dipoligami, karena di dalam komunitas tersebut istri-istri yang dipoligami saling menguatkan satu sama lain.

\section{Peran Modal Dalam Keluarga Poligami}

Pemikiran Bourdieu tentang modal mencakup tentang kemampuan untuk melakukan kontrol terhadap masa depan diri sendiri dan orang lain. Ia merupakan pemusatan segala kekuatan dan hanya bisa ditemukan dalam sebuah ranah. Di satu sisi, masyarakat dibentuk oleh perbedaan distribusi dan penguasaan modal. Di sisi lain, individu juga berjuang memperbesar modal mereka. Hasil dari pembagian dan akumulasi modal inilah yang nantinya menentukan relasi dan status mereka di dalam masyarakat (Bourdieu, 1993:112).

Dalam kasus pernikahan poligami dalam tiga keluarga dalam studi ini, alokasi modal ini yang pada akhirnya menentukan posisi antara suami dan istri. Berdasarkan temuan di lapangan, ketiga suami memiliki alokasi modal yang lebih besar dibandingkan dengan istri. Alokasi modal yang dapat dijadikan sebagai perbandingan dalam menentukan posisi antara suami dan istri dapat dilihat dari empat macam aspek, diantaranya adalah:

\section{Modal Ekonomi}

Dalam perihal modal ekonomi, alokasi modal ekonomi suami lebih besar dibandingkan dengan istri. Hal ini dapat dilihat berdasarkan peran suami dalam keluarga poligami sebagai pencari nafkah, berdasarkan hasil pengamatan peneliti dapat diketahui bahwa suami memiliki kekuatan finansial yang cukup besar, hal ini dapat dilihat melalui luas tanah, bentuk rumah, dan pekerjaan suami. Seperti yang terlihat pada keluarga Hfd, di mana Hfd memiliki pekerjaan untuk mengisi seminar berbayar dan menjual obat keperkasaan laki-laki. Selanjutnya pada keluarga Rrm, suami

\footnotetext{
${ }^{9}$ Hasil wawancara dengan Egd (35 Tahun), penggiat poligami, sekaligus ketua Yayasan Keluarga Samara Indonesia, di Bandung pada Jumat, 27 November 2020.
} 
berprofesi sebagai pengusaha susu perah dan obat kecantikan. Selain itu pada keluarga Egd, suami berprofesi sebagai karyawan dari usaha yang dilakukan oleh Rrm.

Sedangkan istri pada ketiga kasus poligami berperan hanya pada urusan domestik, istri tidak diharuskan untuk ikut serta dalam urusan pencarian nafkah, sehingga istri tidak memiliki kemandirian secara ekonomi. Sehingga istri tidak memiliki alokasi modal ekonomi yang cukup.

2. Modal Budaya

Dalam perihal modal budaya, alokasi modal budaya suami lebih besar dibandingkan dengan istri. hal ini dapat dilihat berdasarkan jenjang pendidikan yang ditempuh oleh suami lebih tinggi dibandingkan dengan istri, dari beberapa informan yang sudah diwawancarai diketahui bahwa pada keluarga Hfd, suami memiliki latar belakang pendidikan $\mathrm{S}$, istri pertama lulusan $\mathrm{S}$, istri kedua lulusan $\mathrm{D} 3$, istri ketiga lulusan SMP, dan istri keempat lulusan SMA. Selanjutnya pada keluarga Rrm suami memiliki latar belakang pendidikan S1, istri pertama lulusan S1, istri kedua lulusan SMA, istri ketiga lulusan SMA, dan istri keempat lulusan SMA. Selain itu pada keluarga Egd, suami memang hanya memiliki latar belakang pendidikan SMA, tetapi suami berperan aktif dalam salah satu organisasi keagamaan.

Selain itu suami berperan aktif sebagai pengurus dalam organisasi keagamaan, sedangkan istri hanya menjadi anggota biasa. Sehingga dapat dipahami bahwa suami memiliki kualifikasi intelektual yang lebih besar dibandingkan dengan istri. Hal ini ditambah anggapan pada tiga keluarga tersebut bahwa suami lebih memiliki akal dibandingkan dengan perempuan yang selalu mengedepankan perasaannnya.

\section{Modal Sosial}

Dalam perihal modal sosial, alokasi modal sosial suami lebih besar dibandingkan dengan istri. hal ini dapat dilihat berdasarkan ikut berperan aktifnya suami dalam organisasi keagamaan, sehingga suami lebih memiliki jaringan sosial yang lebih luas dibandingkan dengan istri yang hanya berperan sebagai anggota biasa dalam organisasi keagamaan. Suami mampu memiliki jaringan sosial yang lebih luas seperti jaringan sosial pada pemuka agama.

Seperti pada keluarga Hfd, suami berposisi sebagai tokoh agama dalam masyarakat, memiliki pesantren, dan tergabung dalam organisasi keagamaan. Selanjutnya pada keluarga Rrm, suami berposisi sebagai salah satu pengurus dalam 
organisasi keagamaan, sedangkan istrinya hanya sebagai anggota. Selain itu pada keluarga Egd, suami berposisi sebagai pengurus sekaligus ketua salah satu organisasi keagamaan, sedangkan istrinya hanya sebagai anggota biasa.

\section{Modal Simbolik}

Dalam perihal modal simbolik, alokasi modal simbolik suami lebih besar dibandingkan dengan istri. hal ini dapat dilihat berdasarkan otoritas yang dimiliki oleh suami dalam keluarga poligami, suami berperan sebagai pemimpin dalam keluarga, sedangkan istri berperan untuk patuh dan taat pada suami. Hal ini diperkuat dengan legitimasi budaya patriarki yang masih kental dalam keluarga poligami yang menganggap bahwa derajat laki-laki lebih tinggi dibandingkan dengan perempuan.

Berdasarkan ketiga kasus keluarga poligami, diketahui bahwa ketiga keluarga ini menganggap bahwa tugas seorang suami adalah sebagai pemimpin, imam, penentu nilai dan norma dalam keluarga, sedangkan istri berperan untuk patuh dan taat pada suami. Hal ini diperkuat oleh anggapan dari istri Rrm dan Egd yang menganggap bahwa suami lebih memiliki akal dibandingkan istri yang lebih mengedepankan perasaannya.

Mereka yang menguasai keempat modal tadi dalam jumlah yang besar, maka akan memperoleh kuasa yang besar pula dan menempati posisi hierarkis tertinggi (kelas dominan). Maka dari itu untuk meningkatkan posisi mereka dalam suatu arena pertarungan dibutuhkan strategi yang digunakan untuk memperoleh pengakuan, otoritas, modal, dan akses atas relasirelasi kuasa (Bourdieu, 1984:125). Karena dalam permasalahan ini suami yang menguasai keempat modal tersebut, maka suamilah yang menjadi aktor yang dominan dan berhak untuk mengatur persepsi perempuan.

\section{Agama Sebagai Wacana Dominan Pada Tiga Keluarga Poligami}

Doxa adalah dunia wacana yang mendominasi kita. Ia merupakan semesta makna yang diterima begitu saja kebenarannya tanpa dipertanyakan lagi. Doxa dapat dimengerti sebagai sejenis tatanan sosial dalam diri individu yang stabil dan terikat pada tradisi serta terdapat kuasa yang sepenuhnya ternaturalisasi dan tidak perlu dipertanyakan lagi (Bourdieu, 1991:138). Ia kemudian menjadi kesadaran kolektif yang dianggap hadir begitu saja tanpa dipertimbangkan lagi. Doxa bisa berupa kebiasaan sederhana seperti cara bicara, cara makan, hingga persoalan kepercayaan.

Untuk membentuk wacana dominan, agama dijadikan sebagai sistem simbol, hal ini dilakukan guna memudahkan terjadinya kesepahaman atau saling pengertian antara suami dan 
istri dalam keluarga. Simbol dapat dijelaskan sebagai alat yang memiliki kekuatan guna memperluas pengamatan kita, membangkitkan daya imajinasi kita, serta memperdalam pemahaman dan penghayatan kita. Ada yang menafsirkan simbol sebagai wadah berkumpulnya makna, ada yang melihat simbol sebagai representasi kebenaran (Dilliston, 2002:18).

Berdasarkan data penelitian yang sudah dilakukan, alasan digunakannya agama sebagai sistem simbol dalam tiga keluarga poligami pada kasus ini adalah karena baik suami maupun istri telah memiliki habitus latar belakang keagamaan. Seperti pada keluarga Rrm yang menganggap bahwa agama merupakan landasan, panduan, ideologi, sedangkan keluarga Egd memposisikan agama sebagai hal fundamental, dan yang utama dalam menjalani kehidupan. Dengan demikian alasan agama dapat dijadikan sebagai sistem simbol dalam keluarga poligami adalah karena kedua aktor ini dapat memiliki kesepahaman dan pemaknaan yang sama tentang agama. Seperti yang dikemukakan oleh Rrm dalam wawancaranya, yaitu:

"Agama itu merupakan sebuah dasar kehidupan, way of life, sebuah hal yang fundamental, solusi kehidupan, tolak ukur segala sesuatu hal, pondasi dalam kehidupan, dan yang paling penting adalah agama itu harus dijadikan sebagai ideologi, jadi kita harus mempercayai dan menjalankan syariat-syariat agama Islam tanpa pandang bulu, termasuk juga tentang poligami." 10

Ketika wacana dominan mendominasi ranah, ia memiliki kemampuan untuk mendefinisikan pada yang lain, maka ada yang berupaya untuk mempertahankan pandangan sahnya ada pula yang berupaya untuk menggugat. Wacana yang bertujuan untuk mempertahankan doxa adalah orthodoxa. Mereka yang berada dibalik wacana orthodoxa adalah kelompok penguasa atau mereka yang dominan dan mendapatkan keuntungan dalam suatu ranah. Sedangkan heterodoxa merupakan wacana yang selalu berusaha untuk menentang doxa. Wacana ini terus mempersoalkan otoritas wacana kelompok dominan dalam mendefinisikan dunia sosial (Fashri, 2014:110).

Pada tiga keluarga poligami dalam kasus ini, suami menggunakan ajaran-ajaran keagamaan yang mendukung dan membolehkan pernikahan poligami, pemahaman menggunakan ajaran keagamaan ini digunakan sebagai sistem simbol untuk membentuk interpretasi istri agar bersedia dipoligami. Pemberian pemahaman ajaran keagamaan tersebut

\footnotetext{
${ }^{10}$ Hasil wawancara dengan Rrm (35 Tahun), penggiat poligami yang tergabung dalam Yayasan Keluarga Samara, di Bandung pada Jumat, 27 November 2020.
} 
bertujuan untuk membentuk pemahaman bagi istri bahwa sebenarnya poligami itu diperbolehkan oleh agama dan terdapat dalam syariat agama Islam.

Suami berusaha menggunakan agama untuk membentuk dunia wacana yang dianggap benar oleh istri dengan cara pemberian pemahaman-pemahaman tentang ajaran keagamaan yang dapat digunakan untuk mempertahankan kuasanya. Seperti pada tiga keluarga poligami dalam kasus ini, suami memberikan pemahaman bahwa sudah menjadi kodratnya suami menjadi pemimpin dalam keluarga, sudah menjadi tugasnya suami untuk menentukan norma, nilai, dan orientasi keagamaan keluarganya, sedangkan istri itu harus patuh dan taat pada suami, dan sudah menjadi kodratnya istri untuk mengurusi urusan rumah tangga, mengurusi anak, dan melayani suami. Seperti yang dikemukakan oleh Hfd dalam wawancaranya, yaitu:

"Ya kalo soal nilai-nilai yang digunakan dalam keluarga itu memang sudah menjadi kewajiban suami untuk menetapkan, malah suami juga wajib untuk mengarahkan konteks keagamaan istri, kan suami itu bertugas untuk membimbing istrinya untuk menuju surganya Allah SWT, kadang juga saya suka bertanya sama istri, baiknya gimana, tapi istri juga tetap menerima segala keputusan yang saya buat, soalnya kan saya mendidik istri tidak hanya dengan perkataan, tapi juga melalui ruhiah, jadi istri percaya dengan kepimimpinan suami." 11

Pemberian pemahaman-pemahaman melalui sistem simbol seperti itu mengakibatkan subordinat tidak mampu untuk membentuk habitus untuk melakukan resistensi, subordinat secara sukarela menerima pemahaman-pemahaman seperti ini dan dianggap sebagai sebuah kebenaran. Hal ini yang pada akhirnya dapat menciptakan langgengnya dominasi yang dilakukan oleh suami, berdasarkan data pada penelitian kali ini, istri bahkan saling menguatkan satu dengan yang lainnya melalui berbagi pengalamannya, berbagi cerita mengenai permasalahan apa saja yang ada dalam keluarga poligami yang kemudian akan dicarikan solusinya oleh komunitas keagamaan. Penjabaran-penjabaran di atas dapat dijelaskan melalui skema No. 2 di bawah ini:

${ }^{11}$ Hasil wawancara dengan Hfd (48 Tahun), Penggiat Poligami, sekaligus direktur Robbanian Family, di Banten pada, Minggu, 08 November 2020. 
Skema No. 2

Agama Sebagai Sebagai Wacana Dominan Pada Tiga Keluarga Poligami

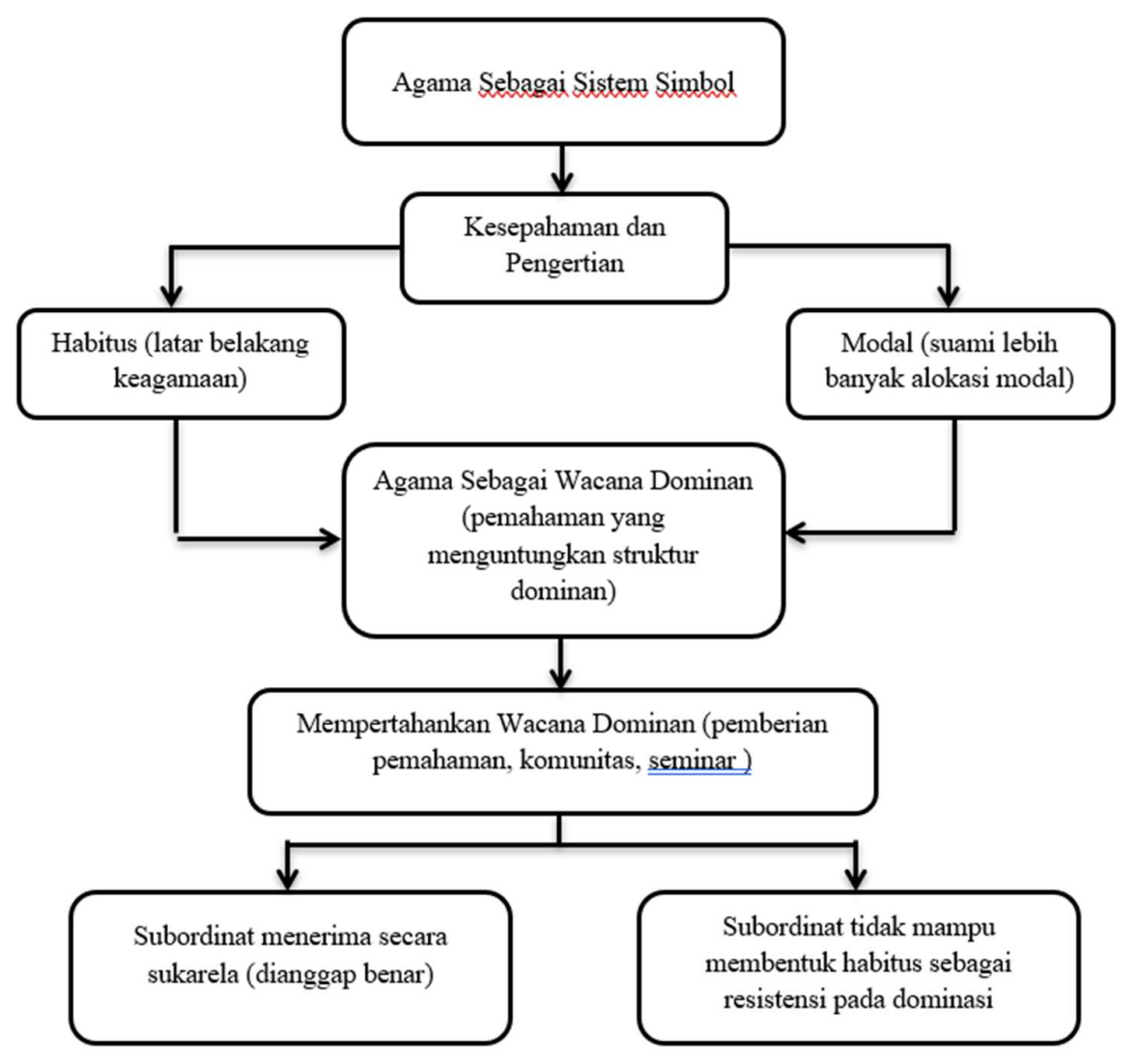

Hasil Interpretasi Penulis (2021)

Berdasarkan skema di atas, dapat disimpulkan bahwa dalam keluarga poligami, sistem simbol yang digunakan adalah sistem simbol agama. Alasan digunakannya agama sebagai sistem simbol dalam keluarga poligami adalah karena baik suami maupun istri telah memiliki latar belakang keagamaan yang baik. Hal ini dilakukan guna memudahkan terjadinya kesepahaman atau saling pengertian antara suami dan istri dalam keluarga. Sistem simbol ini dibentuk dan dipengaruhi oleh latar belakang keluarga, suami, dan komunitas keagamaan. Agama sebagai sistem simbol juga dapat digunakan sebagai wacana dominan karena dalam penerapnnya sistem simbol dapat dibentuk oleh struktur dominan untuk mempertahankan kuasanya.

\section{Relasi Kuasa Pada Tiga Keluarga Poligami Dalam Perspektif Kekerasan Simbolik}

Memahami kuasa dan kekerasan simbolik meniscayakan pemahaman kita akan peran bahasa sebagai sistem simbol. Menurut Borudieu, selain berperan sebagai alat komunikasi dalam memahami dan menyampaikan pikiran serta perasaan antar manusia, bahasa memiliki 
peran laten yang seringkali tidak disadari, yaitu sebagai praktik kuasa. Dengan menggunakan simbol-simbol bahasa, ideologi yang terdapat dibaliknya dapat disemaikan perlahan-lahan secara tidak kentara. Tidak hanya terdiri dari sekumpulan kata-kata yang bermakna bagi pemahaman, lebih jauh bahasa dapat dijadikan sebagai instrumen kekerasan untuk mendapatkan legitimasi dan memperebutkan kesempatan mendefinisikan realitas. Dominasi terhadap simbol merupakan kuasa yang dapat membuat orang mengenali dan mempercayai, memperkuat dan mengubah pandangan mengenai dunia (Bourdieu, 1991:166).

Seperti data di lapangan yang ditemukan, dalam pernikahan poligami seperti yang terlihat dalam ketiga keluarga dalam kasus studi ini relasi yang terjalin antara suami dan istri tidak setara, di mana suami berposisi menjadi yang dominan sedangkan istri berposisi sebagai subordinat. Seperti pada tiga keluarga poligami dalam kasus ini suami berperan sebagai pemimpin dan kepala keluarga dalam keluarga poligami. Pada keluarga Hfd suami bertugas untuk memberikan pemahaman-pemahaman dan mengatur orientasi keagamaan keluarganya. Selanjutnya pada keluarga Rrm dan Egd suami bertugas sebagai pengambil keputusan tertinggi, di mana suami memberikan visi, rencana, dan pemahamannya untuk merekayasa dan membentuk pemahaman istri agar patuh dan taat pada suami. Sedangkan pada tiga keluarga poligami pada kasus ini istri hanya bertugas dalam permasalahan domestik belaka, seperti mengurus urusan dapur, mengasuh anak, dan melayani suami. Seperti yang dikemukakan oleh Rrm dalam wawancaranya, yakni:

\footnotetext{
"Suami itu kan memang sudah menjadi kodratnya untuk menjadi pemimpin bagi perempuan, memang sudah menjadi fitrahnya laki-laki itu sebagai pemimpin, perempuan yang dipimpin, karena kan memang dari struktur tubuhnya berbeda, perannya berbeda, pemkirannya berbeda. Gak akan beres itu keluarga kalo perempuan yang dijadikan sebagai pemimpin, tugas perempuan itu kan hanya untuk patuh dan taat pada suami." 12
}

Selain peranan dari suami, untuk mempertahankan kuasa yang dimiliki oleh suami adalah dengan dimasukannya istri dalam komunitas keagamaan yang berfokus pada pernikahan poligami. Dalam komunitas keagamaan tersebut istri diberikan pemahaman-pemahaman yang mendukung dan melanggengkan dominasi laki-laki pada pernikahan poligami, salah satu contohnya adalah dengan memberikan pemahaman bahwa poligami itu merupakan sebuah syariat agama Islam, tidak ada kerugian bagi istri untuk bersedia dipoligami, sudah menjadi kodratnya istri untuk patuh dan taat pada suami, serta penanaman pemahaman bahwa

\footnotetext{
12 Hasil wawancara dengan Rrm (35 Tahun), penggiat poligami yang tergabung dalam Yayasan Keluarga Samara, di Bandung pada Jumat, 27 November 2020
} 
bersedianya istri untuk dipoligami adalah bentuk ketaatan pada syariat agama Islam dan dapat menjadi lumbung pahala bagi istri.

Peranan komunitas dalam melanggengkan dominasi laki-laki dapat dilihat dari peranan komunitas yang berfungsi sebagai wadah bagi istri-istri yang dipoligami untuk berbagi cerita dan pengalamannya sebagai istri poligami, selain itu istri-istri yang dipoligami juga membagikan kisah tentang permasalahan-permasalahan yang muncul dalam keluarga poligaminya. Komunitas berperan untuk mencarikan solusi terbaik bagi keluarga poligami tersebut sehingga pernikahannya menjadi langgeng dan sistem dominasi laki-laki terus berlanjut. Dalam keluarga poligami, peranan istri dibatasi oleh suami dengan cara hanya memperbolehkan keterlibatan istri dalam keluarga hanya dalam beberapa hal saja, tidak semua permasalahan yang terjadi dalam keluarga membutuhkan keterlibatan istri.

Faktor-faktor tersebut yang pada akhirnya menyebabkan istri memiliki anggapan bahwa pemahaman-pemahaman yang diberikan oleh suami merupakan sebuah sistem objektif dan dianggap sebagai suatu hal yang wajar dan memang sudah menjadi kodratnya perempuan untuk patuh dan taat pada suami. Hal ini yang pada akhirnya menyebabkan perempuan tidak mampu untuk membentuk habitus sebagai resistensi dalam sistem dominasi laki-laki pada pernikahan poligami. Penjabaran-penjabaran di atas dapat dijelaskan melalui skema No. 3 di bawah ini: 
Skema No. 3

\section{Relasi Kuasa Pada Tiga Keluarga Poligami Dalam Perspektif Kekerasan Simbolik}

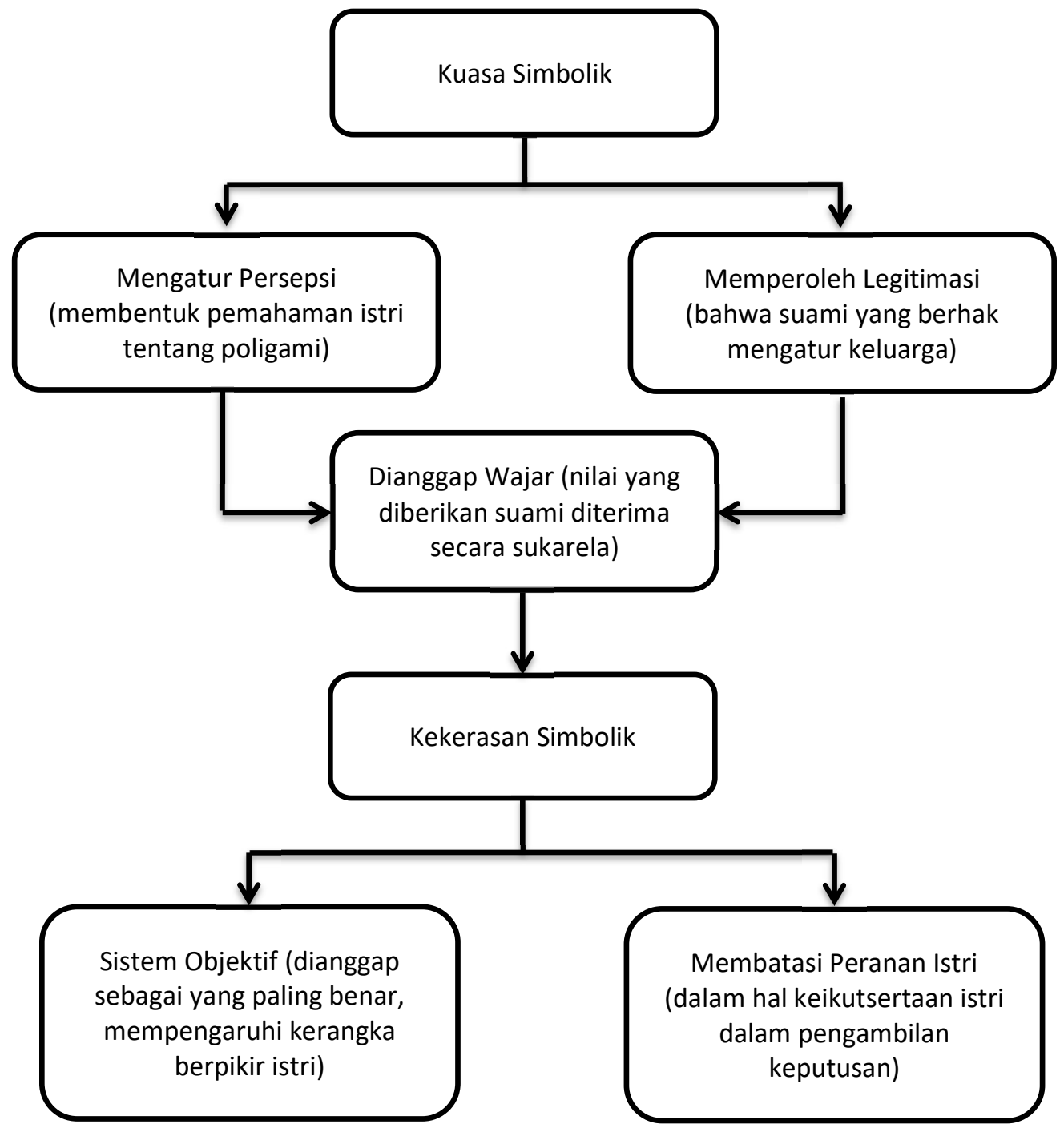

Hasil Interpretasi Penulis (2021)

Berdasarkan skema di atas, dapat ditarik pemahaman bahwa kontestasi dalam pernikahan poligami dimenangkan oleh laki-laki, sehingga laki-laki memiliki kuasa simbolik dan berhak untuk mengatur persepsi istri dan mendapatkan legitimasi kuasa dalam keluarga. Dominasi ini dianggap wajar dan tidak diketahui oleh perempuan, dominasi yang dilakukan secara halus ini yang dinamakan sebagai kekerasan simbolik. Kekerasan simbolik dapat langgeng dilakukan pada keluarga poligami karena pemahaman suami dianggap sebagai struktur yang objektif, selain itu dominasi yang dilakukan suami dilanggengkan melalui pembatasan peranan istri, suami selalu memberikan pemahaman yang dapat meredam resistensi dari istri. 


\title{
Relasi Kuasa Pada Tiga Keluarga Poligami Dalam Komunitas Keagamaan
}

Dalam perspektif kekerasan simbolik, permasalahan pernikahan poligami dianggap sebagai sebuah kompetisi antar pelaku sosial yakni antara suami dan istri yang bertujuan untuk memperoleh kuasa. Kuasa yang dituju merupakan kuasa untuk mengontrol persepsi, pandangan, visi, juga cara pandang seseorang maupun kelompok sosial. Ajang perebutan memperoleh kuasa haruslah dimaknai sebagai upaya untuk memproduksi dan menampilkan pandangan dunia yang paling diakui, yang paling benar, dan yang paling sah. Kesemuanya bermuara pada kepentingan untuk memperoleh legitimasi atau pengakuan bahwa hanya pandangan "mereka" lah yang dianggap paling benar. Kuasa untuk membentuk dunia sosial seperti itulah yang disebut dengan kuasa simbolik (Bourdieu, 1991:165).

Seperti data lapangan yang ditemukan ketiga suami yang berposisi sebagai superordinat dapat mengendalikan simbol-simbol dan mengonstruksi realitas melalui tata simbol tersebut. Agama sebagai tata simbol digunakan oleh suami untuk mendominasi perempuan, bentuk dominasi pada keluarga poligami adalah diberikannya pemahaman pada perempuan bahwa poligami itu merupakan sebuah syariat agama Islam, dan sudah menjadi kodratnya istri untuk patuh dan taat pada suami. Tata simbol yang diberikan kepada istri selalu simbol-simbol yang menguntungkan laki-laki, hal ini menyebabkan dominasi yang dilakukan oleh suami dapat terus dilakukan. Seperti yang dikemukakan oleh Hfd dalam wawancaranya, yakni:

\begin{abstract}
"Sebagai suami untuk membentuk kepatuhan istri adalah dengan cara pemberian pemahaman tentang agama bahwasanya memang sudah menjadi kodratnya istri itu untuk patuh dan taat pada suami, selain itu kita sebagai suami harus menunjukan superioritas kita sebagai suami, contohnya adalah dengan menanggung semua kendali atas pengambilan keputusan dan tanggung jawab dalam keluarga, kan istri jadi klepek-klepek tuh sama kita, dan ini yang terakhir dan paling kunci, yaitu kejantanan suami di ranjang, kalo suami perkasa di ranjang istri mau diapain juga akan nerima aja."13
\end{abstract}

Selain itu bentuk kendali suami dalam mempertahankan wacana dominan pada keluarga poligami adalah dengan memberikan suri tauladan yang baik. Selanjutnya adalah dengan memberikan pemahaman dan argumentasi yang membentuk pemahaman istri, pemberian pemahaman yang dilakukan bisa dengan memberikan pemahaman tentang kitab suci dan syariat agama. Yang terakhir adalah dengan meruntuhkan argumentasi dari istri dengan melakukan debat. Seperti yang dikemukakan oleh Rrm dalam wawancaranya, yakni:

\footnotetext{
${ }^{13}$ Hasil wawancara dengan Hfd (48 Tahun), Penggiat Poligami, sekaligus direktur Robbanian Family, di Banten pada, Minggu, 08 November 2020.
} 
"Untuk membentuk pemahaman istri dan mengikuti keyakinan suami adalah dengan melakukan suri tauladan yang baik, selain itu suami harus memberikan pemahamannya kepada istri, selanjutnya adalah kita kasih tau tentang Al-Quran dan Assunnah, dan yang terakhir apabila masih terdapat prasangka dari istri harus kita runtuhkan argumentasi istri melalui debat."14

Suami berada pada posisi yang mendominasi karena kepemilikan suami akan modal ekonomi, modal budaya, modal sosial, dan modal simbolik. Alokasi modal yang dimiliki oleh suami lebih besar daripada yang dimiliki oleh istri, alokasi modal tersebut diantaranya adalah modal ekonomi yang dimiliki suami lebih besar karena suami berperan sebagai pencari nafkah, sedangkan perempuan bekerja pada bidang domestik, pada modal budaya intelektual laki-laki lebih tinggi dibandingkan dengan perempuan, hal ini dapat dilihat dari jenjang pendidikan suami lebih tinggi dibandingkan dengan perempuan, selain itu laki-laki dianggap lebih memiliki akal dalam pemahaman keagamaan dibandingkan dengan istri, pada modal sosial jaringan sosial yang dimiliki oleh suami lebih besar dibandingkan dengan istri, suami memiliki jaringan sosial pada tokoh-tokoh keagamaan, pada modal simbolik otoritas yang dimiliki oleh suami lebih besar dibandingkan dengan istrinya, suami berperan sebagai pemimpin dalam keluarga, sedangkan istri berperan untuk patuh dan taat pada suami.

Ketika mereka menerima begitu saja, tidak menyadari pemaksaan yang ditanamkan lewat simbol tersebut, maka pada saat itu praktik kuasa simbolik bekerja. Kuasa simbolik adalah kuasa yang bekerja melalui simbol-simbol bahasa untuk menggiring mereka yang didominasi mengikuti makna yang diproduksi berdasarkan kepentingan yang mereka yang mendominasi. Dalam menyembunyikan dominasinya, kuasa simbolik menggunakan cara-cara yang sangat halus agar tidak dikenali. Karena begitu halusnya praktik dominasi yang dijalankan, korban tidak menyadari bahwa yang terjadi adalah praktik kuasa (Bourdieu, 1991:166).

Pernyataan di atas diperkuat dengan literature sejenis yang membahas terkait politik identitas yang ditampilkan oleh perempuan Salafi tentunya dipengaruhi oleh lingkungan kelompoknya. Diri perempuan Salafi sebagai subjek lebih banyak direpresi dan digantikan oleh diri perempuan sebagai objek kuasa. Konstruksi kelompok Salafi telah menentukan identitas tentang bagaimana ketujuh informan dalam penelitian ini seharusnya berpikir, bersikap, dan berperilaku (Ayu, 2017:196).

\footnotetext{
${ }^{14}$ Hasil wawancara dengan Rrm (35 Tahun), penggiat poligami yang tergabung dalam Yayasan Keluarga Samara, di Bandung pada Jumat, 27 November 2020.
} 


\section{Kekerasan Simbolik Pada Tiga Keluarga Poligami Dalam Komunitas Keagamaan}

Dalam menyembunyikan dominasinya, kuasa simbolik menjalankan bentuk-bentuk yang halus agar tak dikenali. Begitu halusnya praktik dominasi yang terjadi menyebabkan mereka yang didominasi tidak sadar bahkan mereka menyerahkan dirinya untuk masuk ke dalam lingkaran dominasi. Dominasi yang mengambil bentuk halus inilah yang disebut Bourdieu sebagai kekerasan simbolik, yaitu sebuah kekerasan yang lembut dan kekerasan yang tak kasat mata. Kekerasan simbolik merupakan suatu bentuk kekerasan yang halus dan tak tampak yang dibaliknya menyembunyikan praktik dominasi (Bourdieu, 1991:168).

Kekerasan simbolik menciptakan mekanisme sosial yang bersifat objektif di mana mereka yang dikuasai menerimanya begitu saja. Mekanisme objektif yang diciptakan kekerasan simbolik memanfaatkan simbol-simbol yang ada untuk memenuhi kehendak untuk berkuasa. Mereka yang mendominasi menyebarkan pengaruh-pengaruh ideologis atau memaksakan pandangan kelompok marginal. Mereka yang didominasi tak sadar kalau mereka sedang digiring untuk menerima atau mengadaptasi pandangan, nilai-nilai, dan kriteria kelas yang berkuasa. Kekerasan simbolik yang mengambil bentuk sangat halus ini tidak akan mengundang resistensi dari subordinat karena ia sudah mendapatkan legitimasi sosial (Bourdieu, 1991:170).

Mekanisme kekerasan simbolik dapat bekerja secara efektif ketika yang didominasi merasakan ketidaktahuan sekaligus mengakuinya. Kekerasan simbolik beroperasi lewat prinsip simbolik yang diketahui dan dikenali oleh kedua belah pihak, yaitu yang mendominasi dan didominasi (Bourdieu, 2002:2). Dalam hal ini kekerasan simbolik dilakukan dengan menggunakan agama sebagai simbol-simbol dalam pembentukan pemaknaan dari istri. Di mana keduanya telah diinternalisasikan pemahaman-pemahaman tentang ilmu agama sejak kecil oleh keluarganya, selain itu mereka menganggap bahwa agama merupakan landasan, panduan, ideologi, fundamental, dan yang utama dalam menjalani kehidupan. Penjelasan mengenai kekerasan simbolik dan kuasa simbolik akan dijabarkan lebih rinci melalui skema No. 4 di bawah ini: 


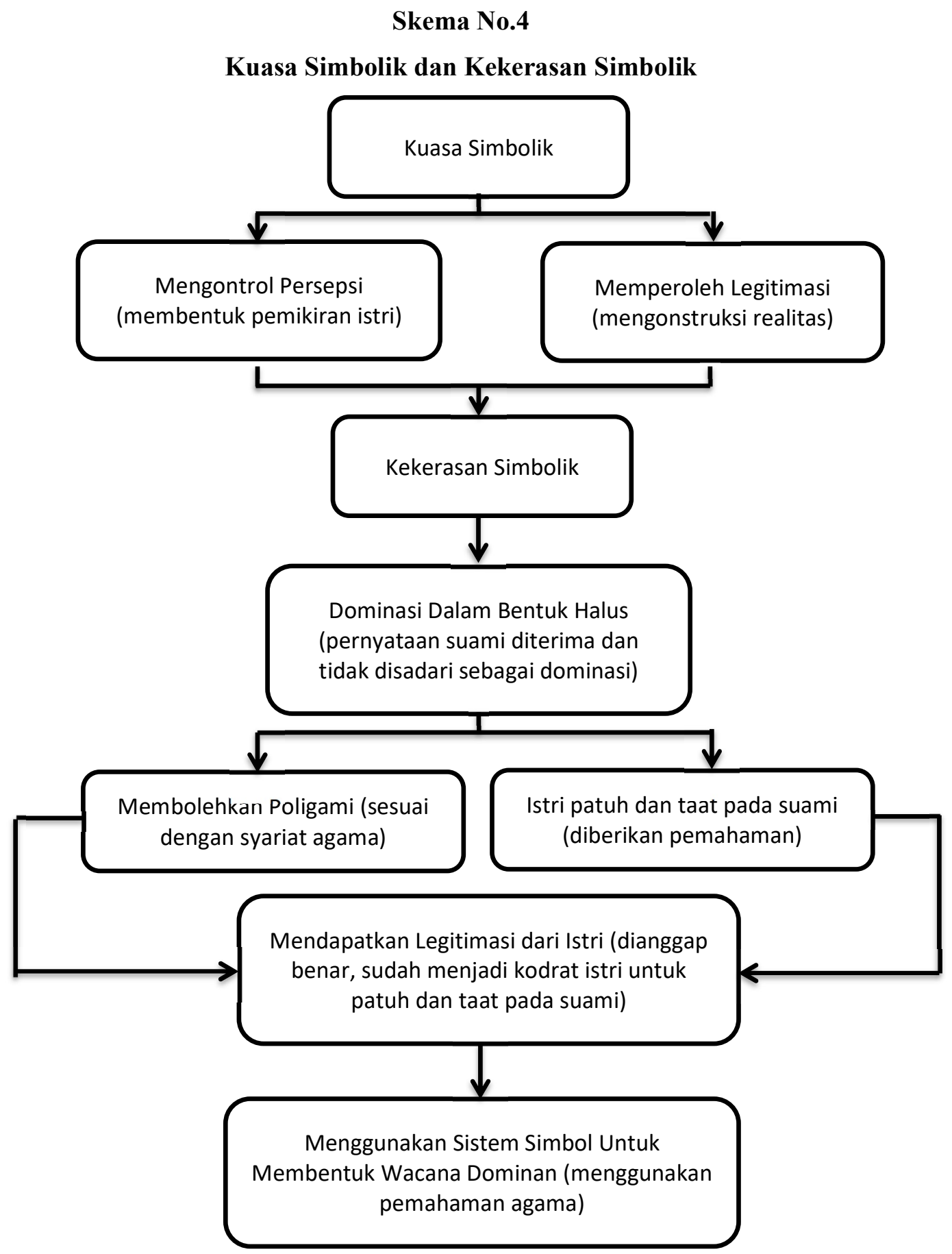

Sumber: Hasil Analisis Peneliti (2021)

Berdasarkan skema No. 4 dijelaskan bahwa kuasa simbolik merupakan kontestasi yang dilakukan dalam sebuah ranah, pada kasus ini ranah yang digunakan adalah ranah rumah tangga. Kontestasi ini ditentukan berdasarkan habitus dan alokasi modal yang dimiliki oleh masing-masing aktor. Pada tiga keluarga poligami pada kasus ini ketiga suami memiliki alokasi modal yang lebih besar dibandingkan istrinya. Kontestasi antar aktor sosial ini pada akhirnya 
bertujuan untuk memperoleh kuasa untuk mengontrol persepsi, pandangan, visi, juga cara pandang seseorang. Selain itu kontestasi yang dilakukan bermuara pada usaha untuk memperoleh legitimasi atau pengakuan bahwa pandangannyalah yang dianggap sebagai struktur objektif, paling sah, dan paling benar.

Kuasa simbolik bekerja dengan menggunakan simbol-simbol sebagai wacana dominan yang turut berperan dalam proses penerimaan wacana dominan terhadap kelompok subordinat yang turut berperan untuk mereproduksi tatanan sosial sesuai dengan kelompok dominan. Dalam menyembunyikan dominasinya, kuasa simbolik menjalankan bentuk-bentuk yang halus agar tak dikenali dan disadari oleh kelompok subordinat. Hal ini menyebabkan mereka yang didominasi menyerahkan dirinya untuk masuk ke dalam lingkaran dominasi. Dominasi dalam bentuk halus ini yang dinamakan Bourdieu sebagai kekerasan simbolik.

Pada tiga keluarga dalam kasus ini, ketiga suami menggunakan sistem simbol untuk membentuk kesepahaman dan pengertian baik dari suami maupun istri. Sistem simbol ini yang akhirnya dijadikan sebagai wacana dominan yang dianggap sebagai struktur objektif, paling sah, dan paling benar. Dalam membentuk wacana dominan dibutuhkan kontestasi dalam ranah rumah tangga untuk menentuka siapakah yang berhak untuk membentuk wacana dominan ini. Kontestasi ini dipengaruhi oleh alokasi modal dan habitus yang dimiliki oleh masing-masing aktor. Pada kasus ini, ketiga suami memiliki alokasi modal yang lebih besar sehingga berhak untuk menentukan wacana dominan. Wacana dominan yang digunakan dalam pernikahan poligami adalah menggunakan agama sebagai wacana yang dipercayai sebagai sistem objektif.

Pada tiga keluarga dalam kasus ini, ketiga suami berusaha untuk memberikan pemahaman-pemahaman agama yang bertujuan untuk membentuk pemahaman istri agar bersedia dipoligami. Beberapa pemahamannya antara lain, pemberian pemahaman bahwa poligami merupakan salah satu syariat agama Islam dan dibolehkan oleh agama, pemberian pemahaman bahwa kedudukan istri dalam keluarga lebih rendah dibandingkan dengan suami, serta pemberian pemahaman bahwa peran istri dalam keluarga adalah patuh dan taat pada suami. Pemahaman-pemahaman seperti ini yang akhirnya membentuk kerangka berpikir istri untuk bersedia dipoligami.

\section{Penutup}

Hasil penelitian ini menunjukan bahwa dalam pernikahan poligami terdapat praktik dominasi antara suami dan istri. Dalam keluarga poligami, keluarga merupakan sebuah arena kontestasi antara suami dan istri dalam menentukan siapa yang mengendalikan sumber wacana 
dalam keluarga. Kontestasi ini dipengaruhi oleh modal dan habitus yang pada akhirnya menentukan posisi antara suami dan istri dalam keluarga poligami. Hal ini yang pada akhirnya membuat aktor yang mendominasi dapat membentuk persepsi, mendapatkan legitimasi, serta dianggap sebagai struktur yang objektif. Kontestasi ini pada akhirnya dimenangkan oleh suami, hal ini bisa terjadi karena alokasi modal dan habitus yang dimiliki oleh suami lebih besar daripada yang dimiliki oleh istri. Kemenangan yang diperoleh oleh suami ini yang pada akhirnya membuat suami berhak untuk menciptakan semesta makna yang dipercayai kebenarannya dan digunakan dalam keluarga.

Agama dijadikan sebagai sistem simbol yang digunakan dalam keluarga poligami, hal ini dilakukan guna memudahkan terjadinya kesepahaman atau saling pengertian antara suami dan istri dalam keluarga. Alasan digunakannya agama sebagai sistem simbol dalam keluarga poligami adalah karena baik suami maupun istri telah memiliki latar belakang keagamaan yang baik. Di mana keduanya telah diinternalisasikan pemahaman-pemahaman tentang ilmu agama sejak kecil oleh keluarganya, selain itu mereka menganggap bahwa agama merupakan landasan, panduan, ideologi, fundamental, dan yang utama dalam menjalani kehidupan. Simbol-simbol yang diproduksi oleh kelas dominan dianggap sebagai sebuah kebenaran oleh subordinat, subordinat menerima secara sukarela tentang pemahaman-pemahaman yang diberikan oleh kelas dominan. Hal ini yang menyebabkan subordinat tidak mampu untuk membentuk sebuah habitus yang mampu menjadi resistensi bagi kelas dominan.

Dalam pernikahan poligami relasi yang terjalin antara suami dan istri tidak setara, di mana suami berposisi menjadi yang dominan sedangkan istri berposisi sebagai subordinat. Hal ini dapat dilihat dari peranan suami sebagai pemimpin dan kepala keluarga dalam keluarga poligami, suami bertugas untuk memberikan pemahaman-pemahaman dan mengatur orientasi keagamaan keluarganya. Selain peranan dari suami, untuk mempertahankan kuasa yang dimiliki oleh suami adalah dengan dimasukannya istri dalam komunitas keagamaan yang berfokus pada pernikahan poligami. Komunitas berperan untuk mencarikan solusi terbaik bagi keluarga poligami tersebut sehingga pernikahannya menjadi langgeng dan sistem dominasi laki-laki terus berlanjut.

Sehingga saran yang dapat diberikan kepada perempuan yang termasuk dalam keluarga poligami diharapkan dapat memahami tentang bagaimana relasi kuasa dan sistem dominasi laki-laki dalam pernikahan poligami. Seperti penguasaan wacana yang dilakukan oleh lakilaki, sehingga perempuan dapat membentuk resistensi yang berujung pada kemandirian 
perempuan dalam keluarga poligami, kemandirian ini yang pada akhirnya dapat meningkatkan posisi perempuan yang sebelumnya berposisi sebagai subordinat. Perempuan diharapkan dapat memperbesar alokasi modal yang dimiliki dan membentuk habitus baru sebagai resistensi pada praktik dominasi laki-laki.

\section{Daftar Pustaka}

Ayu, Prima. 2017. Praktik Kekerasan Simbolik Dalam Pemaknaan Perempuan Bekerja Menurut Manhaj Salafi. Riayah. Vol. 2. No. 01.

Barlian, Eri. 2016. Metodologi Penelitian Kualitatif dan Kuantitatif. Padang: Sukabina Press. Baswardono, Dono. 2007. Poligami Itu Selingkuh, Yogyakarta: Galangpress.

Bourdieu, Pierre. 1984. Distinction. London: Routledge.

Bourdieu, Pierre. 1991. Language \& Symbolic Power. Cambridge: Polity Press.

Bourdieu, Pierre. 2001. Masculine Dominastion. Stanford University Press.

Bourdieu, Pierre. 1993. The Field of Cultural Production. US: Columbia University Press.

Bourdieu, Pierre \& Loic Waqcuant. 1992. An Invitation to Reflexive Sociology. Chicago: The University of Chicago Press.

Dilliston, F.W. 2002. The Power Of Symbols, Yokyakarta: Kanisius.

Dzulkarnain, Iskandar. 2011. Peran Organisasi Perempuan Islam Menghapus Ketidakadilan Gender Terhadap Keluarga Berpoligami di Sumenep Madura. Jurnal Pamator. Vol. 4, No. 1.

Haryatmoko. 2016. Membongkar Rezim Kepastian; Pemikiran Kritis Post-Strukturalis. Yogyakarta: PT Kanisius.

Hikmah, Siti. 2012 Fakta Poligami Sebagai Bentuk Kekerasan Terhadap Perempuan. Jurnal Sawwa. Vol. 7, No. 2.

Muthmainnah, Yulianti. 2019. Aisyiyah Dan Ijtihad Berkemajuan Untuk Hak-Hak Perempuan. MAARIF. Vol. 14. No. 2.

Nurdin, Ismail dan Sri Hartati. 2019. Metode Penelitian Sosial. Surabaya: Media Sahabat Cendikia.

Sulaiman, Zulfitri Zulkarnaen. 2019. Kritik Terhadap Fikih Poligami: Studi Atas Pemikiran Siti Musdah Mulia. Jurnal Al-Mizan. Vol. 15. No. 1.

Takwin, Bagus. 2006. Habitus: Perlengkapan dan Kerangka Panduan Gaya Hidup, dalam Resistensi Gaya Hidup: Teori dan Realitas. Yogyakarta: Jalasutra. 
Wargadiredja, Arzia Tivany. Berikut Catatanku Setelah Ikut Kopdar Pegiat Poligami Garis Keras: https://www.vice.com/id_id/article/yw4gyv/berikut-catatanku-setelah-ikutkopdar-pegiat-poligami-garis-keras. 